\title{
NEWSPAPERS EFFECT ON STUDENTS' WRITING ACHIEVEMENT ACROSS ENGLISH PROFICIENCY LEVELS
}

\author{
${ }^{1}$ Rizky Amelia; ${ }^{2}$ Abdul Muth'im \\ Universitas Lambung Mangkurat, Indonesia ${ }^{1,2}$ \\ Corresponding email: rizky.amelia@ulm.ac.id
}

\begin{abstract}
Exposure is one of the obvious obstacles in the process of teaching and learning English. To figure out one prospective exposure in students' daily life, this study investigates the effect of newspapers as a medium in enhancing students' English achievement, especially writing skill. The objective of this study is to find out whether students assigned to read English newspapers write better than those who are not. The subjects of the study were 85 English department students who were randomly assigned to an experimental group and a control group. A quasiexperimental design was employed in this study. For six executive weeks, before the students were asked to write, the students in the experimental group were assigned to read English newspapers, whereas then students in the control group were not. By using Mann-Whitney and one-way ANOVA tests, the results of this study show insignificant results $(0,273$; 0,194; and 0,179). As the high proficient students also could not take the newspapers for their learning benefits, affective and intrinsic factors such as awareness and willingness had to be considered.
\end{abstract}

Keywords: newspapers, writing achievement, proficiency levels

\section{INTRODUCTION}

Lecturers spend their time, thoughts, and energy for their classroom. They use various media and teaching strategies in teaching English especially where English is a foreign language. Among many available media and teaching strategies, some of them have been studied for instance collaborative writing (Siahaan, 2014), short writing (Kurniawan, 2015), peer and self-directed feedback (Amelia, 2016), and mobile assisted language learning (Hadi \& Anggaira, 2017).

In reality, the results are still students produce mediocre work despite the good implications from the previous studies that have been mentioned. Simple problems such as unfinished sentence or simple, compound, complex, and compound-complex sentences appear on English Department 
students' thesis. In fact, the material of dependent and independent clauses is given at the beginning of writing course series. This material is the foundation for students in writing although teaching writing has always been challenging and difficult (Mastura et al, 2020; Erniyati, 2020). Therefore, students are supposed to master the types of sentences when they are on the stage of writing their Sarjana's thesis as their latest stage to finish the study.

One of the efforts to help students cope with this simple but prominent problem of the mastery of dependent and independent clauses is providing good input. The input of good writing is good reading. As writing was done from a set of rules and principles (Sokolik in Nunan, 2003), a good reading source is written following the correct rules and principles of writing. One of the lecturers' tasks is then providing good reading sources.

In countries where English plays a role as a foreign language, the English reading sources are limited. However, it is not impossible to find ones. Concerning with the principles for teaching reading and writing skills, newspapers fits to be used. From the eight principles for teaching reading by Brown and Lee (2015), the use of newspapers in teaching reading covers four of them namely offering a reading on relevant, interesting, and motivating topics, balancing authenticity and readability in choosing text, encouraging the development of reading strategies and building ongoing assessment into the techniques. Meanwhile, from nine principles for teaching writing, the use of newspapers in teaching writing covers the account for cultural/literacy background, connects reading and writing, provides as much authentic writing as possible, and provides conventions of writing.

Even though studies on the use of newspapers in teaching English are rarely found, some studies have been done by several researchers. Tafida and Dalhatu (2014) used newspapers to teach various levels of students and found that it improved their English achievement. Mehta's study (2010) also showed that the use of newspapers encourages and motivates students as well as sharpens students' language skills (Listening, Speaking, Reading, and Writing). Ahmed's study in 2016 was conducted to 30 first year of masters' students of Dhaka University. It shows that the use of reading newspapers improves the students' vocabulary and reading skills gradually. Meanwhile, Anil (2017) conducted a qualitative study using innovative teaching methods in a second language classroom in India. She used newspapers, media, movies, interpreting advertisements, and creating Sandblot. It was found that the use of newspapers is a positive way for students to learn the language meaningfully. Different from the previous studies, this study focuses on one innovative teaching method only that is the use of newspapers on students' writing achievement across English proficiency levels namely low and high to provide clear contrast. This study 
offers an alternative for the setting where English is spoken as a foreign language to which the exposure is limited.

In studying English itself, students' proficiency varies widely. It is known by the term of English proficiency levels. Among some standardized English proficiency tests, TOEFL-like or English Proficiency Test (EPT) is chosen for this study since this test fits the academic needs. Regardless the opinion that TOEFL did not provide any writing section, the multiple-choice test of structure and written expression section were still used to make statements about a student's potential writing ability in an academic context (Latief, 1991: 95-96; Weir, 1993:14). In other words, it was included in the indirect measurement method. In addition, TOEFL is still believed to give a clear picture of how proficient is someone and is able to map the students' proficiency in English.

The students are classified based on their scores. The students' scores are listed, and three levels (high, moderate, and low) are made based on the scores. This selection cannot be done by deciding which scores belong to what levels at the very beginning since there is the possibility of varieties results of their proficiency. For the illustration, it is possible that only five students are at the high level, ten students are at a moderate level, and thirteen students are at a low level. As a result, classifying them by their actual scores manually is chosen. The control and the experimental groups' TOEFL scores in the high and low levels are tried to be a balance of not having a far difference. There is also a point to be considered in TOEFL that the students who are in the moderate level were not involved in the data analysis for the ease to see a clear contrast of the proficiency.

In this study, besides maximizing the use of newspapers, English proficiency levels are taken into account as they form a point of difference. Moreover, by involving 85 English department students, the objective of this study is to find out whether the students assigned to read English newspapers write better than those who are not, across proficiency levels. To present a clear picture of this study, the related literature review, method, findings, discussion, and conclusion are described in the next sections of this paper.

\section{METHOD}

This study employed a quasi-experimental research. It is aimed to investigate the effect of newspapers on the students' writing achievement. For six executive weeks, before the students were asked to write, the students in the experimental group were assigned to read English newspapers, whereas then students in the control group were not. The consideration of this treatment is that because newspapers play a role as the exposure in the process of teaching and learning English (Noom-ura, 2013). 
The effect is also observed from the English Proficiency Levels particularly the high and low levels. Therefore, the research questions to be answered in this study are formulated as follows:

1. Do students who were taught using newspapers have better writing achievement than those who were not taught using newspapers?

2. Do students with high English proficiency level who were taught using newspapers have better writing achievement than those who were not taught using newspapers?

3. Do students with low English proficiency level who were taught using newspapers have better writing achievement than those who were not taught using newspapers?

\section{Research Subjects and Setting}

The research subjects of this study were the people who fit the conceptual definition for this study. They were the second semester students of English Language Education Study Program Faculty of Teacher Training and Education, Universitas Lambung Mangkurat, Banjarmasin, Indonesia. The students took Guided Writing class. They were experimentally suitable, accessible, and available. They fit the criteria of being experimented to generalize the results under this study.

\section{Instruments}

The data of this study was collected by using a writing test as the post-test. The writing test was developed to measure the students' writing achievement. The students in both control and experimental groups were asked to write a paragraph based on the given topics. This writing test was classified in the direct measurement method, and it represents the students' writing skill. The data from the students writing was obtained and analyzed as the post test data. This data was scored by two raters. The sheets that were used during the treatment were also functioned to see the progress that the students made during the learning.

\section{Data Collection}

Since this study employed a quasi experimental study, these students were randomly assigned to an experimental group and a control group. The treatment was given for six executive weeks. In the experimental group, the students were assigned to read English newspapers. Meanwhile, the students in the control group were not assigned to read English newspapers.

In the experimental group, the lecturer provided as well as asked the students to buy the English newspapers (Jakarta Post). However, the newspapers were not limited in the printed ones only. The students can reach the online version on their smartphone. They could download and 
read it anywhere and anytime. About the title of the articles in the newspapers, the students could choose any topic they like. During the treatment, the newspapers were used to introduce all the sentence types. The students were asked to find the simple, compound, complex, and compound-complex sentences by themselves. On the process, they were provided an evaluation sheet on every sentence type (Appendix 1) to assist them in learning using newspapers.

\section{Data Analysis Procedures}

In the data analysis, the researchers conducted a preliminary statistic by analyzing obtained data for fulfilling the statistical assumptions on the homogeneity and normality testing. Then, to answer the first research question, the gathered data was analyzed by using the Mann-Whitney test since the data was not normally distributed. After that, the one-way ANOVA test was used in analyzing the data to answer the second and third questions since the data was homogeneous and normally distributed. Finally, the last step to analyze the data was making a decision of accepting or rejecting the null hypotheses.

\section{FINDINGS}

\section{The Results of the Students' English Proficiency Levels}

Prior to the treatment of this study, the subjects' TOEFL scores were recorded. The lowest score was obtained by the student in the experimental group (283), and the highest score was attained by the student in the control group (540). Table 1 demonstrates the brief results of the students' classification based on their English proficiency levels.

Table 1: The Results of the TOEFL-like in the Control and Experimental Groups

\begin{tabular}{lcclll}
\hline & $\mathrm{N}$ & Mean & $\begin{array}{l}\text { Std. } \\
\text { Deviation }\end{array}$ & Minimum & Maximum \\
\hline Control Group & 43 & 413 & 55.69872 & 313 & 540 \\
Experimental Group & 42 & 378 & 48.19013 & 283 & 523 \\
Valid N (listwise) & 42 & & & & \\
\hline
\end{tabular}

The results of the descriptive statistics of the TOEFL scores above were used to group the students in high and low proficient students in both groups. The same number of students was 10 for each small group. The moderate proficient students' scores were not analyzed considering to see the contrast of these comparable groups. 


\section{The Results of the Control and the Experimental Groups' Post-test}

All students in control and experimental groups finished the posttest. The data in the experimental and control groups were homogeneous $(0,323)$, but it was not normally distributed $(0,014$ and 0,282$)$. Therefore, Mann-Whitney test was used to analyze the data to answer the first research question. The obtained result was 0,237 showing the insignificant result. The complete results of the post-test can be seen in Table 2 .

Table 2: The Results of the Control and Experimental Groups Post-test

\begin{tabular}{|c|c|}
\hline & Scores \\
\hline Mann-Whitney U & 780,000 \\
\hline Wilcoxon W & 1726,000 \\
\hline Z & $-1,096$ \\
\hline $\begin{array}{l}\text { Asymp. Sig. (2- } \\
\text { tailed) }\end{array}$ & 273 \\
\hline
\end{tabular}

Unlike the statistical assumption of the first research question, the data in both groups of the students with high English proficient ability was homogeneous $(0,450)$ and normally distributed $(0,437$ and 0,999$)$. Since the data was homogeneous and normally distributed, the ANOVA test was used. The result is sig 0,194 which is also insignificant.

Table 3: The Results of the Control and Experimental Groups Post-test with High Proficient Students

\begin{tabular}{llllll}
\hline & \multicolumn{2}{l}{ Sum of } & & Mean \\
Squares & df & Square & F & Sig. \\
\hline Between & 118,080 & 1 & 118,080 & 1,781 &, 194 \\
$\begin{array}{l}\text { Groups } \\
\text { Within Groups }\end{array}$ & 1723,661 & 26 & 66,295 & & \\
Total & 1841,741 & 27 & & & \\
\hline
\end{tabular}

Then, in low proficient-ability students, the data was also homogeneous $(0,287)$ and normally distributed $(0,536$ and 0,654$)$. Similar to the second analysis, by using the ANOVA test, the result is 0,179 showing insignificant result.

Table 4: The Results of the Control and Experimental Groups Post-test with Low Proficient Students

\begin{tabular}{llllll}
\hline & \multicolumn{2}{l}{ Sum of } & & Mean \\
& Squares & df & Square & F & Sig. \\
\hline Between & 162,723 & 1 & 162,723 & 1,909 &, 179 \\
$\begin{array}{l}\text { Groups } \\
\text { Within Groups }\end{array}$ & 2216,518 & 26 & 85,251 & & \\
Total & 2379,241 & 27 & & & \\
\hline
\end{tabular}




\section{DISCUSSION}

The presence of newspapers in education is not a novel idea. It was evident from the establishment of Newspapers in Education (NiE) by newspaper publishers worldwide aiming to build literacy by providing educational materials to schools and colleges. $\mathrm{NiE}$ itself was designed to help teachers teach children about newspapers, how they work, and how to use them. Now, NiE exists in more than 80 countries according to the research by the World Association of Newspapers and News Publishers (WAN-IFRA). In addition, based on the previous studies results concerning the use of newspapers in the classroom, this present study fulfills the gaps as it is conducted in the writing skill and across English proficiency levels.

The first research question was initially set, and the statistical analysis by using the Mann-Whitney test was carried out. The result of the first research question is surprising that it is insignificant. The results revealed there was no significant difference in the writing achievement in the students who are taught by using newspapers and those who are not taught by using newspapers. The result of this study is in contrast with Francis and Dhanavel (2016), Tafida and Dalhatu (2014), and Lancouchova (2006) as they claim that newspapers are ideal teaching material. However, it is in line with Barkova's study (2011) that found the difficulties and pitfalls of using newspapers in the classroom. They are double-take headlines, false friends of an interpreter, new meanings, buzz words, and jargon.

Jirousova (2015) stated that the use of newspapers seems to be a challenge. Even though it is a positive challenge for students, she also claimed that newspapers should be included in the lessons for students to succeed in English real life. In line with Jirousova (2015), Cornish (2004) suggested that students can even create Web versions of their newspaper to broaden their audience. Student-created newspapers are an excellent way to teach most writing skills and promote the classroom or school in the community.

The commencement point of the second and third research questions of this study concerning the English proficiency levels also show insignificant results. Previous studies on English proficiency levels are scarce. Tafida and Dalhatu (2014) investigated language learning activities using newspapers to teach ESL students at elementary, intermediate, and advanced levels.

They recommend that the English lessons should be activity-based, some features of newspapers in English language textbooks, functional libraries and regular supply of newspapers should be provided, and activities and materials should promote students' participation. Meanwhile, a study conducted by Namata in 2010 was conducted in different types of schools. They are rural, urban and peri-urban areas. In his study, Namata (2010) used newspapers as tools for literacy in Uganda. The study was done 
on how the NiE program contributes to the improvement of primary education in Uganda. This study recommends deliberate efforts to be made at home, school and policy levels to create a favorable environment for the $\mathrm{NiE}$ program to succeed. Thus, the insignificant results of this present study show that the high proficient students also could not take the newspapers for their learning benefits.

Possible explanation for these insignificant results is that more carefully research design on the use of newspapers in writing class is needed. The researchers of this study have provided the evaluation sheet for the ease of use during the learning. Unfortunately, it is predicted that the students implement this in the classroom only. Even though the students are accustomed to reading English newspapers, the Jakarta Post, in Reading class, they solely do it as the demand of the lecturer. In other words, it is not based on their willingness. This predictive obstacle is related to students awareness to study English through reading and expose themselves with the sources of English. Since the time allotment to study English is limited, it is expected that the students realize to learn independently.

Moreover, length of the time to conduct the study should also be taken into account. As this study was conducted in one semester, it is possible that longer time is needed. Another possible limitation of this study is that in the other context, for instance, English as a Second Language or Native Language, the use of of newspapers in the classroom is possible to use due to the ease. The applicability of the use of newspapers in English as a Foreign Language (EFL) classroom needs more research studies to support or against these insignificant results. Then, in relation to English proficiency levels, it is possible that the high proficient students understand the lessons better than the low proficient students do, but it is not with the use of newspapers in the classroom. Despite the insignificant results of this study, the use of newspapers in writing class facilitates students to enrich their knowledge, motivates them to read and discuss, and provide good examples of a correct set of rules and principles in writing.

\section{CONCLUSION AND SUGGESTION}

This study with a three-fold purpose namely to investigate the effect of newspapers in writing achievement, to investigate the effect of newspapers in writing achievement of high proficient students, and to investigate the effect of newspapers in writing achievement of low proficient students showed insignificant results. Recognizing the cchallenges of using newspapers in a writing class, this study provides implications on using newspapers in the field of EFL education. This study plays a role to initiate further relevant studies on the use of newspapers in EFL classroom by 
considering a careful design of the treatment, involving motivation as one of the variables, and conducting as a longitudinal study.

\section{REFERENCES}

Ahmed, R. (2016). Effectiveness of reading English newspapers forimproving vocabulary and reading skills of students of Dhaka university. The Millennium University Journal, 1(1), 68-76.

Amelia, R. (2016). The Effectiveness of peer and self-directed feedback on writing ability as observed from English proficiency levels. Unpublished Thesis. Malang: PPs UM.

Anil, B. (2017). Applying innovative teaching methods in a second language classroom. International Journal of Research in English

Education, 1(1), 1-9.

Barkova, L. (2011). Challenges and rewards of teaching a newspaper class. International Journal of Business and Social Science, 2(15), 71-74.

Brown, H.D. \& Lee, H. (2015). Teaching by principles: An Interactive approach to language pedagogy ( $4^{\text {th }}$ ed). Whiteains, NY: Pearson Education, Inc.

Castello, D. (2015). First language acquisition and classroom language learning: Similarities and differences. Published Thesis. United Kingdom: University of Birmingham.

Cornish, J. (2004). Newspapers in the classroom. Accessed on www.classroom.com.

Francis, D.P. \& Dhanavel, S.P. (2016). Developing the writing skill of semiurban and rural engineering students through reading skills. The English Classroom Bi-annual Journal, 18(2), 46-55.

Hadi, M.S. \& Anggaira, A.S. (2017). The use of mobile assisted language learning (MALL) in teaching writing. 15th Asia TEFL \& 64th TEFLIN International Conference. Yogyakarta 13 - 15 July 2017.

World Association of Newspapers and News Publishers (WAN-IFRA) accessed on http://www.wan-ifra.org/microsites/youthengagement-news-literacy.

Jirousova, E. (2015). Using newspapers to teach English grammar and vocabulary. Published Thesis. Czech Republic: Graduate Study of Brno.

Kurniawan, Y. (2015). Short Writing: An alternative to improve students' writing skills. The paper presented at the 62nd TEFLIN International Conference, Denpasar 14 - 16 September 2015.

Lancouchova, B. (2006). Using magazines and newspapers in ELT with interpersonal and intrapersonal types of students. Published Bachelor Work. Czech Republic: Undergaduate Study of Brno.

Latief, M. A. (1991). Scoring the quality of classroom essay. TEFLIN Journal: An EFL Journal in Indonesia, 4(1), 94-112. 
Mehta, N. K. (2010). English newspapers: Exploring innovative methodological paradigm. A study into classroom dynamics. Romanian Journal of Education, 1(1), 55-60.

Namata, W. (2010). Newspapers as tools of literacy in Uganda: A case study of daily monitor's newspapers in education (NiE) programme addressing literacy-related issues in Uganda's primary education. Published Thesis. Norway: Graduate Study of University of Oslo.

Noom-ura, S. (2013). English-teaching problems in Thailand and Thai teachers' professional development needs. English Language Teaching Journal, 6(11), 139-147.

Siahaan, A. U. (2014). The Effect of Collaborative Writing on EFL Students' Writing as Observed from Their Personality Learning Styles. Unpublished Thesis. Malang: PPs UM. Skills. The paper presented at the 62nd TEFLIN International Conference, Denpasar $14-16$ September 2015.

Sokolik, M. (2003). Exploring skills: Writing. In David, N (Ed.), Practical English Language Teaching, (pages 87-108). Singapore: Mc-Graw Hill.

Tafida, A. G. \& Dalhatu, B. M. (2014). Using newspapers in teaching English as a second language. Journal of Educational Research and Reviews, 2(5) 61-65.

Weir, J. C. (1993). Communicative Language Testing. Trowbridge: Prentice Hall. 


\section{Lesson Plan}

\section{Appendix 1}

Objectives:

The student will be able to:

* use background knowledge to complete the "K" column.

* write simple sentences s/he sees from the newspapers.

* produce her/his own simple sentences.

* discuss what s/he has learned.

\section{Materials:}

newspapers

KL handout: Simple Sentence

whiteboard

LCD

whiteboard

boardmarkers

\section{KL Handout: Simple Sentence}

Write three simple sentences that you found on the newspapers article. 1.

2.

3.

Theme:

Title:

Author:

Page

Is the article long?

Read an article from the newspaper and copy three simple sentences from the article.

1.

2.

3. 
Rizky Amelia; Abdul Muth'im

Write your opinion in one sentence about the article that you have read.

What punctuations used in this article?

Do you find new vocabulary items from the article? If it is yes, write them down. 